УДК 378.1: 339.9

UDC 378.1: 339.9

DOI: $10.31475 /$ ped.dys.2020.28.09

НАДІЯ ГУПКА-МАКОГІН,

кандидат педагогічних наук

(Украӥна, Тернопіль, Західноукраӥнський національний університет, вул. Львівська, 11)

NADIYA HUPKA-MAKOHIN,

Candidate of Pedagogical Sciences (Ukraine, Ternopil, Western Ukrainian National University,

ORCID: 0000-0003-0146-9540

\title{
Методологічні засади формування англомовної професійно орієнтованої аудитивної компетентності студентів економічних спеціальностей
}

\section{Methodological Backgrounds of the English Language Professionally Oriented Listening Competence Formation of Economic Specialty Students}

У статті теоретично проаналізовано та науково обгрунтовано зліст бборлування англоловної проббесійно орієнтованої колпетентності в аудіюванні студентів еконолічних спеціальностей. Встановлено законолірності структури та колпонентного складу систели навчально-виховного процесу в немовнолу вищолу закладі освіти. Представлені результати контрольних зрізів навчання майбутніх еконолістів англоловного профбесійно орієнтованого аудіювання на основі яких виокреллено вилоги до англоловного пробесійно орієнтованого аудіювання у відповідності до видів аудіювання, а сале: розуління основного злісту аудіотексту, що передбачає передусіл розуління майбутніл працівникол сббери еконоліки тели й найсуттєвіших деталей аудіотексту; аудіювання з метою пошуку необхідної інфборлаціӥ чи інфбормацї, яка иікавить, передбачає розуління студентол конкретної інборлаціӥ; аудіювання 3 повним розулінням аудіотексту передбачає розуління студентом максилально повної $і$ точної його інфборлаиї. Здійснено порівняльний аналіз профбесійно спрялованих улінь в аудіюванні, які виступають складовою колунікативно-пробесійної колпетенції студентів еконолічних спеціальностей.

Ключові слова: аудитивні вління; методичні підходи; неловні заклади вищої освіти; проббесійно орієнтована аудитивна колпетентність; студенти-еконолісти.

The content of English professionally oriented competence in listening of the students of economic specialties has been theoretically analyzed and scientifically substantiated in the article. The regularities of the structure and component composition of educational process in a non-linguistic higher education institution have been established.

The typology of competences for future specialists in economics and the main methodological approaches to the formation of English language professionally oriented listening in a non-linguistic higher educational institution have been characterized to develop new methods of self-study English professionally oriented listening of the future economists for enhancing their competitiveness at the labour market.

At the present stage of the society development, the ultimate goal of learning a foreign language in the non-linguistic higher educational institution is to develop the personality of economic specialties students to be mobile and capable of self-education, self-realization and participation in foreign language intercultural communication. The implementation of the educational process can be complete only if the professional component is taken into account. Therefore, we see the prospects for further research considering the components of the content of English vocational listening in a non-linguistic higher educational institution to develop a methodology for forming English vocational listening of the future economists that will promote the mobility of bachelors and their competitiveness.

The results of the training control of English-speaking professionally oriented listening of the future economists have been presented, on the basis of English-speaking professionally oriented listening requirements in accordance with the types of listening have been singled out, such as: understanding of the main content of the audio text, which involves first of all the understanding of the future employee of the economics of the topic and the most important details of the audio text; listening to find the necessary information or information of interest involves the student's understanding of specific information; listening with a full understanding of the audio text involves the student's understanding of the most 
complete and accurate information. A comparative analysis of professionally oriented listening skills, which are part of the communicative and professional competence of students of economic specialties, has been carried out.

Key words: auditory skills; methodical approaches; non-linguistic institutions of higher education; professionally oriented auditory competence; students-economists.

Introduction / Вступ. Updates in the system of foreign language vocational education in a nonlinguistic institution of higher education occur simultaneously with changes in the development of social demand: a foreign language becomes a means of intercultural professional communication, and reproductive education is modified into developmental in the context of competence approach.

The modernization of modern professional foreign language higher education has caused a need for the formation of English-speaking professional competence in listening of the future professionals and the need for effective teaching methods and organization of the educational process of auditory skills in economic specialties to achieve the required level of the future employee for implementing professional, business and intercultural foreign language communication. Highlighting the components of the content of education, N. Galskova emphasized the urgency of attracting authentic materials of the future employee's profession field (Galskova N., 2000). In addition, I. Passov investigated the strategic components for updating the system of foreign language training of future specialists (Passov I., 2001). According to the Program for English for Specific Purposes, the second year students of non-linguistic higher institutions must be able to hear and understand short conversations in the field within the topics defined by the program, using a standard emphasis in video and audio (Bakaieva H., 2005). Following the Common European Framework of Reference for Languages, professional listening skills, such as the ability to understand clear messages spoken at a moderate speed in professional situations, should be developed from level B1; ability to understand the main ideas of radio and television programs on topics related to professional activities; ability to understand the main information of lectures on professional issues, provided that they are pronounced clearly at a moderate pace and with a normative pronunciation. At level B2, professionally oriented skills are aimed to understand lectures, seminars and messages related to the professional sphere, if they are pronounced clearly and the topic is familiar; the ability to perceive from speech specific information related to professional activities, provided at a moderate pace and with normal pronunciation. At the $\mathrm{C} 1$ level, the future employee of the economic sphere must be able to identify various accents and styles in speech, be able to understand lectures, discussions and debates on professional topics (Nikolaieva S., 2003).

The peculiarities of foreign language professionally oriented training of economists in Ukraine involves the formation of English professionally oriented listening competence based on reflective, personality-activity and competence approaches (Zadorozhna I., 2012). This concept is based on the principles of step-by-step foreign language training of both the future specialist in general and the employee of the economic sphere in particular; variability of professional, fundamental and humanitarian training; professional orientation of foreign language training; interdisciplinary approach of the educational process; individual and creative approach to the student of non-linguistic higher education institution; humanization of the whole learning process (Bihych O., 2013).

Aim and Tasks / Мета та завдання. The purpose is to analyze the methodological foundations of the formation of English-speaking professionally oriented audio competence of students of economic specialties at the present formation and development stage of our society.

Objectives: to substantiate the effectiveness of the method of forming listening competence of the future professionals in the field of international economics in the self-study process, to test the effectiveness of the subsystem of exercises, as well as to determine a more optimal version of student learning method.

Methods / Методи. The research work was conducted on the basis of Ternopil National University of Economics (TNEU), in the I-II semesters of 2019-2020 among 62 students studying in the field of training 051 «International Economics». Investigating the independent research activities of future workers in the field of economics, like M.Kniazian, we consider the reflection of the individual as a guarantee of its adequate self-perception and self-esteem, formation of self-concept, critical thinking. According to M. Kniazian, the reflexive component is a system-forming component of lifelong learning (Kniazian M., 2006).

We agree with N. Koryakovceva that the personal-activity approach involves the construction of the educational process not only through the logical system construction of the subject, but also through the development of second language personality, improvement of its internal state and individual program of professionally oriented foreign language, where the leading category of personality-communicative approach in the context of listening skills formation is the student's personality and his/her educational activity (Koryakovceva N., 2002). 
Regarding the competence approach, the term «competence» in listening, means the ability of the future worker in the field of economics to listen to authentic texts of different genres and types with different levels of understanding of the content in direct and indirect communication. Competence approach in terms of teaching foreign language in non-linguistic higher education istitution and the formation of professionally oriented listening skills, in particular, determines the presence of the student in the center of the system of professional foreign language education (Zadorozhna I., 2008; Ovcharuk O., 2009).

The study includes the following stages: 1. Theoretical analysis and selected methodological prerequisites of the study, as well as methods of teaching professionally oriented English listening of future professionals in the field of international economics in the self-study process. 2. Formulation of the research hypothesis: the effectiveness of professionally oriented English listening formation and improvement will influence significantly the process of self-study methodology, which is based on personality - communicative activity, reflexive and professionally oriented approaches; provides for the simultaneous development of educational and strategic competence as the basis of educational autonomy, the gradual formation of professionally oriented English-speaking competence in listening. 3. Formation of the strategy of conducting experimental sections: (I stage - introductory, aimed at developing students' psychophysiological mechanisms of listening (speech hearing, mechanism of recognition and identification, mechanism of anticipation, mechanisms of long-term and short-term memory, mechanism of articulation, mechanism of comprehension); II stage - preparatory, the purpose of which is the development of listening skills, introducing educational strategies; III stage implementation, designed to develop the skills of introductory, selective, detailed listening; IV stage final, aimed at improving listening skills and developing the ability to analyze and use the obtained information). 4. Conducting experimental sections, which involved the use of the appropriate subsystem of exercises and training website as a learning tool. 5. Theoretical analysis of the results of the study, the establishment of relationships between the structural elements of the process of formation of professionally oriented English listening competence and the conclusions.

Results / Результати. Pursuing the goal of determining the place of teaching of professionally oriented English listening in the system of professional training in non-linguistic higher education institution, we will characterize the typology of competences that should be formed by the future employees of the international economy.

Following O. Solovova, we single out five main competences that are leading to the development of national educational standards of non-linguistic higher education institutions in the European and world community that provide the graduates of non-linguistic higher education institutions with the mobility to adapt and at modern world labor market. 1) Socio-political competence, which involves the psychological readiness of the specialist to solve problems and take responsibility for them. 2) Informative competence is defined as a set of willingness and need to work with modern modernized sources of information in the domestic and professional spheres; to find the necessary information, process it, store it and use it to solve various tasks. 3) Communicative competence - is necessary for successful professional functioning, and it must be formed in both native and foreign languages. 4) Socio-cultural competence is not only one of the components of communicative competence, but it is realized independently for the professionally oriented purpose of teaching foreign language.

5) Readiness and ability to lifelong vocational education (Solovova E., 2004).

The basic competences of the employee of the economic field are presented in the table below (Table 1).

Table 1

The basic competences of the employee of the economic field

\begin{tabular}{|c|c|c|c|}
\hline \multicolumn{3}{|c|}{ The competences of the workers in the field of economy } \\
\hline $\begin{array}{c}\text { Sociopsychological } \\
\text { competence }\end{array}$ & $\begin{array}{c}\text { Foreign } \\
\text { communicative } \\
\text { and professional } \\
\text { competence }\end{array}$ & $\begin{array}{c}\text { General professional } \\
\text { competence } \\
\text { competence }\end{array}$ & $\begin{array}{c}\text { Subject } \\
\text { realization }\end{array}$ \\
\hline \multicolumn{5}{|c|}{} & I stage & I stage \\
\hline I stage & $\begin{array}{c}\text { General professional } \\
\text { competences }\end{array}$ & $\begin{array}{c}\text { Special professional } \\
\text { competences }\end{array}$ \\
\hline
\end{tabular}


Sociopsychological competence presupposes the readiness of the future worker in the field of international economics to solve professional tasks within the framework of intercultural communication.

Both the foreign language communicative competence and foreign language professional competence constitute an integral characteristic of the professional activity of the future specialist, which covers activity and communicative substructures. Activity substructure is knowledge, skills, abilities and ways of carrying out professional activities, and communicative is knowledge, skills, abilities and ways of realization of foreign language professional communication (Tynkaliuk O., 2006).

Following T. Nedashkivska, general economic professional competence is presented as the system of professional competences provided by the position of the future employee of the economic field and personal traits of the employee that determine the level of knowledge and skills that he/she can effectively apply in different situation and adapt to changing conditions (Nedashkivska T., 2008).

Subject competence of students of economic specialties involves the development in the learning process of experience specific to a particular subject of activity related to the acquisition of new knowledge, its transformation and application.

Professional self-realization implies the socialized way of harmonious development of personality, combined with gaining professional-practical and spiritual experience in the process of obtaining a specialist's qualification in the period of initial professional development (higher education) and improving professional growth in the process of performing professional roles and responsibilities.

Therefore, we can distinguish the requirements for English professionally oriented listening in accordance with the types of auditions (Nikolayeva S., 2003). 1) Understanding the main content of the audio text, involves primarily understanding of the topic and of the most important details of the audio text. It is enough to understand $75 \%$ of the information, provided that the remaining $25 \%$ does not contain key information essential for understanding the entire content of the audio text. This type of listening involves the formation of the future specialist's ability to predict the content of audio text by its title, guess the meaning of unfamiliar lexical units, ignore individual lexical units that do not interfere with understanding of the main content, determine the semantic parts of the text and connections between them; 2) Listening to find the necessary information, specific information that may be given.The future specialist should quickly find the necessary information and concentrate on it, trying to understand the information fuly or its main content (depending on the communicative guidelines). This type of listening involves the formation of the student's ability to navigate in the logical and semantic structure of audio text, finding and choosing new or given information, combining logically obtained information from several audio sources. The accuracy of understanding of the audio text is determined by the correctness of the student's answer to the teacher's question about whether the future employee of the international economy is interested in such information, which part of the audiotext was the most informative, whether the received material is new to the student; 3) Listening with a full understanding of the audio text involves the student's understanding of the most complete and accurate information. This type of listening requires the formation of the student's ability to combine listening with simple mnemonic and logical-semantic activities, evaluate and compare the acquired information with their experience.

Discussion / Обговорення. Our experiment was educational, as it involved mastering the students' professionally oriented listening competence; natural, because it was conducted in real learning conditions without changing the composition of groups; open, as it provided with the possibility of making certain changes in the process of conducting the experiment; vertical-horizontal - the vertical nature of the experiment was ensured by testing the effectiveness of the developed method before and after experimental training; horizontal - the focus on determining better option for students to master listening skills in the self-study process. To ensure the reliability of the experimental results, it was necessary to determine the criteria for assessing the level professionally oriented listening competence formation.

Taking into account the pecularities of future professional activity, types of listening and levels of understanding of audio information and the criteria of students' listening skills were determined: - understanding the general content of the message; $\cdot$ understanding the detailed content of the message; - perceiving of specific information; - ability to analyze the received information. We checked the level of professionally oriented listening competence formation in pre-experimental and post-experimental sections with the help of tests. The test is defined as a task of standard form, the implementation of which allows to establish the level and availability of certain knowledge, skills and abilities using a special scale of results (Zadorozhna I., 2012). The level of understanding of the general content of the message, in particular, is advisable to be checked by using the technique of "true-false» (True-false), which is easy to conclude and evaluate; multiple choice test, the convenience of which is the speed of counting the correct answers, the lack of produced answers, which is appropriate for 
receptive types of speech activity, the impossibility of ambiguous understanding of the issue, «Crossselection", which involves comparing and combining units from opposite blocks (for example, comparing the speaker with the statements he/she made). To check the understanding of the detailed content of the message, you should use the technique of «true-false» (True-false); multiple choice test; reception "cross-selection»; technique of "information transformation", which consists of the transformation of the written text by filling in a table, plan, diagram, diagram, tracking the route; gapped text technique for inserting individual words and phrases in missing spaces; answers to questions (Zadorozhna I., 2012).

Conclusions / Висновки. Thus, we distinguish the following professional and communicative skills of the future worker in the field of international economics: mastery of professional terminology and the ability to negotiate; ability to solve problem situations at the appropriate level of foreign language professional communication; ability to communicate on professional topics, if it is necessary to act as an intercultural mediator during negotiations, knowledge of socio-cultural features of the English professional terminology.

The purpose of teaching future economists is the formation of professionally oriented listening skills, which are part of communicative and professional competence. The following skills and abilities that ensure successful English professionally oriented listening have been determined: the ability to distinguish the boundaries of the sentence (actually the development of intonation - the identification of ascending and descending tones); skills to highlight important information in a sentence with intonation and marker words; skills to recognize individual lexical units and their grammatical forms, to guess the meaning of unfamiliar words - the formation of language guess (the ability to guess the meaning of new language material); skills to identify general linguistic meaning by indication of cause and effect, contrast, enumeration, addition of information, classification or ordering of information by profession, reference; skills to recognize word-markers that signal the structure and auditory flow of information - indicate the introductory part, the main part and the final part; ability to use abbreviations and own abbreviations; the ability to determine the main and additional provisions of the flow of information, to identify details that carry a significant information, the ability to ignore details of an unimportant information; ability to identify redundant information; ability to understand examples, explanations and other applications in an authentic statement.

At the present the ultimate goal of teaching English in non-linguistic higher education institution is to develop a mobile personality, capable to participate in foreign language intercultural communication. The implementation of the educational process can be complete only if the professional component is taken into account.

Therefore, we see prospects for further research in considering the content of the components of the English professionally oriented listening competence teaching at non-linguistic education institutions to develop a methodology for teaching future economists, which will promote the mobility of bachelors in economics and strengthen their competitiveness at the labor market.

\section{Список використаних джерел і літератури:}

Гальскова, Н. Д. (2000). Современная методика обучения иностранным языкам. Москва: АРКТИ [in Russian].

Загальноєвропейські рекомендацї̈ з мовної освіти: вивчення, викладання, оцінювання. (2003). (Наук. ред. С. Ю. Ніколаева). Київ: Ленвіт [in Ukrainian].

Задорожна, І. П. (2008). Компетентнісний підхід у сучасній системі мовної освіти. Вісник Київського національного лінгвістичного університету, 14, 10-14 [in Ukrainian].

Задорожна, І. П. (2012). Теоретико-методичні засади організації самостійної роботи майбутніх учителів з оволодіння англомовною комунікативною компетенціею. (Дис. д-ра наук). Київ [in Ukrainian].

Князян, М. О. (2006). Самостійно-дослідницька діяльність майбутніх учителів іноземних мов: теорія $i$ практика: [моногр.]. Ізмаїл: Сміл [in Ukrainian].

Компетентнісний підхід у сучасній освіті: світовий досвід та украӥнські перспективи. (2004). (Заг. ред. О. В. Овчарук). Київ: К.І.С. [in Ukrainian].

Коряковцева, Н. Ф. (2002). Современная методика организации самостоятельной работы изучающих иностранный язык. Москва: АРКТИ [in Russian].

Методика навчання іноземних мов і культур: теорія і практика. (2013). (Бігич, О. Б. та ін.; за заг. ред. С. Ю. Ніколаевої). Київ: Ленвіт [in Ukrainian].

Недашківська, Т. (2008). Професійність державних службовиів: компетентнісний підхід. Взято з http://www.nbuv.gov.ua/portal/soc gum/znpnadu/2008 1/05\%20Derz.pdf [in Ukrainian].

Пассов, Е. И., \& Кузовлев, В. П. (2001). Мастерство и личность учителя. На примере деятельности учителя иностранного языка. Москва: Флинта [in Russian].

Програма з англійської мови для профбесійного спілкування. (2005). (Бакаєва, Г. Є. та ін.). Київ: Ленвіт [in Ukrainian].

Соловова, Е. Н. (2004). Методическая подготовка и переподготовка учителя иностранного языка: интегративно-рефблективный подход. Москва: ГЛОССА-ПРЕСС [in Russian].

Теорія і практика формування іншомовної профбесійно орієнтованої компетентності в говорінні у 
студентів нелінгвістичних сеціальностей: [кол. моногр.]. (2013). (Бігич, О. Б. та ін; за заг. та наук. ред. О. Б. Бігич). Київ: Вид. центр КНЛУ [in Ukrainian].

Тинкалюк, О. Сутність і структура іншомовної колунікативної компетенцї студентів немовних спеціальностей вищих http://www.lnu.edu.ua/Pedagogika/periodic/visnyk/24/06_tynkalyuk.pdf [in Ukrainian].

\section{References:}

Galskova, N. D. (2000). Sovremennaya metodika obucheniya inostranny'm yazy'kam [Modern Procedure of Training to Foreign Languages]. Moscow: ARKTI [in Russian].

Nikolaieva, S. (Ed.). (2003). Zahalnoievropeiski rekomendatsii z movnoi osvity: vyvchennia, vykladannia, otsiniuvannia [Pan-European Recommendations for Language Education: Study, Teaching, Assessment]. Kyiv: Lenvit [in Ukrainian].

Zadorozhna, I. P. (2008). Kompetentnisnyi pidkhid u suchasnii systemi movnoi osvity [Competence Approach in Modern Language Education System]. Visnyk Kyivskoho Natsionalnoho Linhvistychnoho Universytetu - Bulletin of Kyiv National Linguistic University, 14, 10-14 [in Ukrainian].

Zadorozhna, I. P. (2012). Teoretyko-metodychni zasady orhanizatsii samostiinoi roboty maibutnikh uchyteliv $z$ ovolodinnia anhlomovnoiu komunikatyvnoiu kompetentsiieiu [Theoretical and Methodical Bases of the Organization of Independent Work of Future Teachers on Mastering of English Communicative Competence]. (Doctor's thesis). Kyiv [in Ukrainian].

Kniazian, M. O. (2006). Samostiino-doslidnytska diialnist maibutnikh uchyteliv inozemnykh mov: teoriia $i$ praktyka [Independent Research Activity of Future Teachers of Foreign Languages: Theory and Practice]. Izmail: Smil [in Ukrainian].

Ovcharuk, O. V. (Ed.). (2004). Kompetentnisnyi pidkhid u suchasnii osviti: svitovyi dosvid ta ukrainski perspektyvy [Competence Approach in Modern Education: World Experience and Ukrainian Perspectives]. Kyiv: K.I.S. [in Ukrainian].

Koryakovceva, N. F. (2002). Sovremennaya metodika organizacii samostoyatelnoj raboty' izuchayuschix inostranny'j yazy'k [Modern Methods of Organizing Independent Work of Foreign Language Learners]. Moscow: ARKTI [in Russian].

Bihych, O. B, \& Nikolaieva, S. Yu. (Ed.). (2013). Metodyka navchannia inozemnykh mov $i$ kultur: teoriia $i$ praktyka [Methods of Teaching Foreign Languages and Cultures: Theory and Practice]. Kyiv: Lenvit [in Ukrainian].

Nedashkivska, T. (2008). Profesiinist derzhavnykh sluzhbovtsiv: kompetentnisnyi pidkhid [Professionalism of Civil Servants: $\quad$ a $\quad$ Competency Approach]. $\quad$ Retrieved from http://www.nbuv.gov.ua/portal/soc_gum/znpnadu/2008_1/05\%20Derz.pdf [in Ukrainian].

Passov, E. I., \& Kuzovlev, V. P. (2001). Masterstvo i lichnost uchitelya. Na primere deyatelnosti uchitelya inostrannogo yazy'ka [Mastery and Personality of the Teacher. On the Example of the Activity of a Foreign Language Teacher]. Moscow: Flinta [in Russian].

Bakayeva, H. (2005). Prohrama z anhliiskoi movy dlia profesiinoho spilkuvannia [English Language Program for Professional Communication]. Kyiv: Lenvit [in Ukrainian].

Solovova, E. N. (2004). Metodicheskaya podgotovka i perepodgotovka uchitelya inostrannogo yazy'ka: integrativno-reflektivny'j podxod [Methodical Training and Retraining of a Foreign Language Teacher: IntegrativeReflective Approach]. Moscow: GLOSSA-PRESS [in Russian].

Bihych, O. B. (2013). Teoriia i praktyka formuvannia inshomovnoi profesiino oriientovanoi kompetentnosti $v$ hovorinni u studentiv nelinhvistychnykh spetsialnostei [Theory and Practice of Formation of Foreign Language Professionally Oriented Competence in Speaking in Students of Non-Linguistic Specialties]. Kyiv: Vyd. tsentr KNLU [in Ukrainian].

Tynkaliuk, O. Sutnist $i$ struktura inshomovnoi komunikatyvnoi kompetentsii studentiv nemovnykh spetsialnostei vyshchykh navchalnykh zakladiv [The Essence and Structure of Foreign Language Communicative Competence of Students of Non-Language Specialties of Higher Educational Institutions]. Retrieved from http://www.Inu.edu.ua/Pedagogika/periodic/visnyk/24/06_tynkalyuk.pdf [in Ukrainian].

Дата надходження статті: «28» квітня 2020 р.

Стаття прийнята до друку: «22» червня 2020 р.

Гупка-Макогін Надія - старший викладач кафедри іноземних мов Західноукраїнського національного університету, кандидат педагогічних наук

Hupka-Makohin Nadiya - Senior Lecturer of the Department of Foreign Languages of Western Ukrainian National University, Candidate of Pedagogical Sciences

\section{Цитуйте цю статтю як:}

Гупка-Макогін, Н. (2020). Методологічні засади формування англомовної професійно орієнтованої аудитивної компетентності студентів економічних спеціальностей. Педагогічний дискурс, 28, 69-74. doi: 10.31475/ped.dys.2020.28.09.

\section{Cite this article as:}

Hupka-Makohin, N. (2020). Methodological Backgrounds of the English Language Professionally Oriented Listening Competence Formation of Economic Specialty Students. Pedagogical Discourse, 28, 69-74. doi: 10.31475/ped.dys.2020.28.09. 